\title{
Integrating Intercultural Education among Arab Speakers in English Classroom
}

\author{
Shahala Nassim ${ }^{1}$, Wided Labidi ${ }^{2}$ \\ ${ }^{1}$ Modern College of Business and Science, Muscat, Oman \\ ${ }^{2}$ Arab Open University, Muscat, Oman \\ Email: shahalasnassim@gmail.com,Wided.1@aou.edu.om
}

How to cite this paper: Nassim, S., \& Labidi, W. (2022). Integrating Intercultural Education among Arab Speakers in English Classroom. Creative Education, 13, 450-465. https://doi.org/10.4236/ce.2022.132026

Received: November 7, 2021

Accepted: February 11, 2022

Published: February 14, 2022

Copyright (c) 2022 by author(s) and Scientific Research Publishing Inc. This work is licensed under the Creative Commons Attribution International License (CC BY 4.0).

http://creativecommons.org/licenses/by/4.0/

\begin{abstract}
Culture is an inseparable part of language education. The paper focuses on the relevance of integrating intercultural education among Arab speakers. The study intends to analyze the impact of task-based learning through cultural education in English classes of Arab speakers at Arab Open University, Oman. The study was designed as a qualitative research for analyzing the effectiveness of integrating intercultural education into English classrooms. It was conducted as a task given to the students in groups where they need to create an e-book. Their e-book should be about a country of their preference and should include the contents that they learned from their coursebook. The students created e-books about four different countries and tried to use the form and structure of their course book. The study helped students to realize the way of contextualizing the learned concept through their e-book by using the vocabulary and grammar of each unit to explain the contents of their e-book. "Canva" graphic design website was used for this task and a rubric was formed to assess their task. Students' perspective about the new approach was also analyzed qualitatively through an open-ended questionnaire. The new strategy of intercultural language learning led them to learn collaboratively, linguistically, and technically comparing and contrasting other countries' culture and way of life.
\end{abstract}

\section{Keywords}

Intercultural Education, Arab Speakers, English Classrooms

\section{Introduction}

"Languages are the bedrock of the world's cultural heritage. Every language offers a rich and unique insight into different ways of thinking and living as well as into the history of the myriad of cultures and peoples across the globe" (British 
Council, 2013). The relationship between culture and teaching language is important. This is equally applicable to Arab-speaking students whose learning instruction language is English. It is important to see possible relationships between learning a language and cultural practice. This article intends to discuss the way of integrating cultural education in English classrooms for Omani students at Arab Open University based on existing literature and theories on the topic.

Learning a second or foreign language goes above merely developing learners' language and communication competence in the target language. It includes conveying knowledge about the target culture or the country in which that language is spoken. According to the views of (Englebert, 2004: p. 37), "to teach a foreign language is also to teach a foreign culture". For an anthropologist, for instance, culture may be defined as people's way of life. Anthropologists' definitions of culture have also been echoed by scholars from other fields, including linguists. For instance, (Brown, 2007: p. 380) defined culture concisely as "the ideas, customs, skills, arts, and tools that characterize a given group of people in a given period of period; the relationship between language and culture is a complex one". This complexity is captured by (Agar, 1994: p. 28) who describes it "Culture is in language and language is loaded with culture". There is minimal separation between learning a language and assimilation of the cultural values of the society which the language is drawn from. Among earlier studies on this topic, (Brooks, 1964) described language as "the most advanced element of culture".

Arabic is one of the world's key languages that is culturally rich. It is spoken by over 300 million people in the Middle East and North Africa, majorly in the countries which form the Arab League (Sayed, 2015). Given the wide background of the Arabic language, the subsequent cultures are equally extensive. Because of globalization and many Arabic-speaking students getting an education from English-speaking countries, their culture and language might be considered for inclusion in their education.

It is imperative to have some practices from the Arabic students' culture. This could include simple tasks like their teachers giving them the "as-salaamu 'Alaykum! (Peace be upon you)" greeting and learning to respond to such greeting as is "Wa Alaykum as-salaam! (And may peace be upon you)". These are probably the two most common phrases in the Arabic language. Inclusion of learners' culture into language learning will lead to identity construction with a better understanding of their culture in the global scene (Al-Siyabi, 2012). In EFL classrooms, students have limitations in getting acquainted with the target culture and thus less chance to become culturally competent. Speaking English to native speakers is not the aim of foreign language learning, but also to communicate with people coming from different countries and cultures. Thus, learning English is a tool to communicate with multicultural people in the field of education, business, science, technology, art, tourism, and entertainment. Therefore, cultural education in English classrooms will expose students to different cultures and their practices which will develop students' inter-cultural commu- 
nication competency (Chlopek, 2008). Cultural awareness for teachers is an inevitable part of the language learning process which helps them to plan culturally oriented pedagogy and a better understanding of each other (Yurtsever \& Özel, 2021). Cultural familiarity is important as it not only helps in understanding the context but also hinders the learning process of students specifically in linguistic skills like reading, listening, vocabulary, and speaking (Al Hsani, 2010). Realizing the importance of cultural education in English classrooms, this study attempts to integrate inter-cultural education in English language classrooms among Arab students and to analyze students' perceptions about the new concept.

\section{Review of Literature}

\section{Importance of Intercultural Education in English classrooms}

(Raddawi, 2015) mentions the importance of intercultural communication among Arabs in the globalized world and having more research into this field. Intercultural communication in academics will help students to deal with people coming from various ethnic backgrounds. Many organizations and governments have given huge support and focus to cultural awareness and the development of cross-cultural teaching methods and systems have followed suit. A quick look at available literature on this subject matter thus indicates that much has been tackled in the recent past.

Tavares and Cavalcanti (1996) narrated in their study dubbed "Developing cultural awareness in EFL classrooms" that aim of teaching culture is to increase learners' cognizance and subsequently develop their knowledge towards the learning and their home culture. Further, an assertion of (Kaikkonen, 2001: p. 64) is that "the most important goal of foreign language education is to help learners grow out of the shell of their mother tongue and their own culture." It is noted also that there is a possibility of improved foreign culture when there is good awareness of one's own culture (Ritlyova, 2009). (Pereira, 2016) pointed in his article that language learning can be easy if students can relate their learning elements in their daily life process and moreover, intercultural learning can enrich their linguistic competence in comparing and contrasting other's life process. Incorporation of these cultures and languages in class is however a challenge due to scarcity of time, teaching resources, and even lack of knowledge on the cultures involved.

While promotion of Arabic cultures by incorporating them in English learning language is a largely welcome idea, there is a risk of it being considered as promotion of foreign language values. Despite the existence of a plethora of studies on foreign language and cultures' partial assimilation, not much has been done in the Arabic perspective. This has largely been occasioned by further diversity in the Arabic cultures by region, and the lack of many English-speaking teachers who understand the Arabic language and cultures. The available literature on this topic will be reviewed to find the perception by learners and teachers on culture-influenced teaching methods. 
Many students from diverse and Arabic cultural backgrounds, who go to learn in English-speaking countries, or migrate to the same, don't usually find learning systems that are in tandem with their culture. This has caused many students from the Middle East to perform poorly and face increased challenges and difficulties that draw negatively on their academic achievements. There is the initial struggle they face of struggling to learn the English language and subsequent adoption of new cultures which they understand very little about. Literature to be reviewed on the extent of these struggles is "Iraqi refugee students: from a collection of aliens to a community of learners: the role of cultural factors in the acquisition of literacy by Iraqi refugee students with interrupted formal education" by Nykiel-Herbert (2010). Poor performance by Middle Eastern students is not because they are not clever, but rather because "their home cultures, while being 'celebrated,' are not sufficiently utilized as the resource for their own learning" (Nykiel-Herbert, 2010). This weighs in on their learning progress because there is so much to learn, within the same timeframe as their English-speaking peers who are already several steps ahead. If these students are put in classrooms with teachers who know their backgrounds and culture, the cross-cultural interaction process will be more simplified, with improved learning outcomes witnessed (Nykiel-Herbert, 2010).

Literature by (Mao, 2009) to be reviewed has tackled factors that necessitate and directly influence the education of culture in English as Foreign Language classrooms to present a mode of culture teaching in China. According to Mao, it is important to take into account the role of culture in EFL classrooms to gain a better understanding of English as a language and ensure successful cross-cultural communication in real situations. (Fushino, 2011) reveals in his study about students' perception in using cultural approach in learning English language. Students admitted that the new approach helped them to gain confidence in using English language and to broaden their perception about other cultures. Students, teachers, and parents together emphasized the importance of integrating cultural education into the curriculum which actually gives equality and openness in a multilingual classroom setting (Buchs \& Maradan, 2021). Thus, there is a huge need to include "teaching of culture" in the teaching of English. This will achieve teaching of the language through the culture.

Teachers should be culturally aware of the diverse cultures in their classrooms to create a more vibrant learning environment for their students. Teachers with such abilities are more successful when incorporating cultural lessons and approaches, better known as Culturally Relevant Pedagogy (CRP), (Ladson-Billings, 1995) thus making better impacts in the cultural applications. According to Lee (2010), CRP is a combination of educational practices that respond to most students from diverse cultural backgrounds and ought to be incorporated in all learning levels. The use of an effective CRP model will easily bridge the cultural differences, making the affected students more responsive, passionate, and better engaged in the curriculum because it carries their own identities 
and relatable experiences. Thus, this wedges a successful transformation from background culture to home the school culture, an achievement which is not usually addressed by the traditional instructional approaches (Lee, 2010).

Another literature to be reviewed is work by Ho, S. T. K. (2009) titled "Addressing culture in EFL classrooms: The challenge of shifting from a traditional to an intercultural stance". In his study, (Ho, 2009) focused on cultural content in tertiary EFL teaching in Vietnam, and the possible impact it has on intercultural language learning on students on the course of EFL. Ho analyzed underlying assumptions on culture embedded in traditional EFL textbook units currently in use at a Vietnamese institution of higher learning. Cultural components in the units were proposed through a set of standards for intercultural language drawn from the literature. The proposals were in effect expected to raise awareness to learners on culture and engage them cognitively, socially, and affectively in culture learning.

In his article "Promoting cultural literacy in the EFL classroom", Naqeeb (2012) based his study on the empowerment of teachers through the provision of essentials to develop cultural literacy in EFL classrooms. Naqeeb arms the teachers with cultural literacy as well as the American Access Micro-Scholarship Program as a model through which cultural literacy is promoted in the EFL classroom. This researcher concluded the paper with a recommendation to policymakers to adopt the new philosophy when teaching the English Language as a foreign language.

Among the most recent literature to be reviewed is "The attitudes of EFL teachers towards teaching culture and their classroom practices" by Karabinar and Guler (2012). They focused their study on describing the attitudes of teachers of language towards the teaching of culture. They found that variation between native and non-native English-speaking teachers is minimal, and equally difference in attitudes by teachers working at state-owned institutions, and those in private universities is equally minimal. Further, they found out that a higher participation rate in "training courses on teaching culture" and "professional development activities" resulted in a more positive attitude towards integrating culture and language.

Though teachers agree on the importance of culture, they still have doubts regarding the cultural aspects to be considered for teaching, when, and how to teach (Al Hsani, 2010). Thorough literature needs to be investigated for a better understanding of different techniques and ways of integrating cultural education.

\section{Ways to Integrate Cultural Education in English Classrooms}

Various studies reflect on the approaches and techniques of integrating cultural education in English language classrooms. Previous studies in Oman and other parts of the world show that there is no one consistent approach in integrating cultural educating in language learning process. Some studies used field ap- 
proach, role play, cultural stories, cultural celebrations while others applied cross comparative way of using cultural education into their classes.

(Tuzlukova \& Al Mahrooqi, 2010) mentions different ways of integrating native culture in classrooms like using articles, newspapers, folktales, books related to the country's culture, and other aspects. In addition, (Al Seyabi, 2010) explains the ways of integrating culture in the English learning process through two case studies. The first case study exposed students to different cultural activities which provided them to use the target language for expressing their culture like a presentation about Omani culture, organizing Omani cultural day, playing traditional Omani games, and conducting interaction programs with children and teachers of other cultures. In the second case study, students were involved in a British-sponsored interaction partnership program namely, 'connecting classrooms' which led students to communicate with UK students. Moreover, (Al Hsani, 2010) suggests various methods that can be used in Oman contexts like using souvenirs, photographs, foreign literature and textbooks, role-playing, and critical reflection of other cultures.

Authentic materials, role-play, literature, folktales, movies, ethnographic studies, proverbs, drama, problem-solving, intercultural communication, creating cultural surroundings, watching movies, and encouraging students to do projects on different cultures are the common types used in cultural studies (Purba, 2011).

(Wei, 2013) explains different cultural activities that were conducted as a part of cultural education. Chinese students were encouraged to study the cultures of other minorities and cooperate with the minorities for celebrating their programs and festivals. The author also tried to bring the ethnic and cultural diversities of different communities of china for cultural awareness of their nation itself.

The article by (Zhao, 2010) revolves around fostering the students' cross-cultural awareness in EFL teaching. Zhao believes that the importance of acquiring foreign culture includes: 1) familiarizing the EFL learner with the everyday circumstances of the English speaking nations, which includes the customs and traditions, lifestyles, general believes on global views, and key holiday among others, 2) to enable EFL learners to understand the relationship between language and the social variables and effects it has on people's way of speaking and conduct; and 3) nurturing the learner's ability to empirically evaluate the culture of the target country. He suggests that the writing of textbooks should be approached from the viewpoint of culture to make them more effective too.

Based on the meta-analysis of 50 culture related studies in ESL/EFL context, the authors (Yurtsever \& Özel, 2021) classified cultural studies into two categories: 1) Foundation in which studies were mainly done through lesson components, connecting with other cultures, and 2) Acquirements in which studies were mainly done by developing intercultural competence, cognitive competence, and global involvement. 
(Abbaspour et al., 2012) describe the four approaches of teaching culture in their article. They are:

1) Intercultural approach: learned through comparison of the target and the learners' own culture.

2) Multicultural approach: focuses on the ethnic and linguistic diversity of the target culture, but also the learners' own culture.

3) Trans-cultural approach: learned through comparison of other cultures and the learners' own culture.

4) Foreign-cultural approach: concept of a single culture and focus on the target culture.

The study also emphasizes certain techniques of cultural education like authentic atmosphere, cultural information, cultural problem solving, literature and humanities, community resource center, and real-life exposure.

A study conducted to analyze the feedback of teachers concluded that teachers believed that culture learning had a big impact in English classes both linguistically and in communicative competence. They used several methods to integrate culture into their classrooms like using a textbook, self-developed materials, providing cultural information, comparing and contrasting cultures, and conducting cultural programs.

Another study implemented cultural learning as a set of goals to be achieved by integrating various activities like cultural awareness, cultural relativity, analyzing social-cultural variables, eliciting stereotypes, and researching other cultures. Technology-based cultural learning is very well explained by (Dema \& Moeller, 2012) in their article. Writing blogs can be used as a platform to reflect on the understandings of different cultures. Listening and publishing a podcast about different cultures. Incorporating the virtual world is another way of showcasing different cultures.

Thus based on the existing literature, the researcher decided to integrate cultural education in an intercultural approach with technology.

\section{Objectives of the Study}

The study intends to integrate cultural education in English classrooms and analyze its effect on the learning process.

1) To analyze the impact of cultural education in the English classroom of Arab speakers.

2) To analyze the perception of students about the new system of learning.

\section{Methodology}

\section{1) Research Design}

A qualitative study approach was designed to assess the effectiveness of integrating intercultural education into language classrooms. The task given to the students was taken to analyze the new approach and students' perception was also analyzed qualitatively by using an open-ended questionnaire. 


\section{2) Sample}

The study was conducted with first level English Foundation students at Arab Open University. The class consisted of 24 students coming from different parts of Oman.

\section{3) Procedure}

The researcher decided to integrate technology based intercultural approach in her English classroom as it was observed that cultural education with technology is very little. Students like to learn with technology as they get exposed to a new platform for the learning process. The cultural study was decided to be an integral part of their study as students were asked to create e-books similar to their English coursebook. Their coursebook consisted of 10 units of different topics like Education, Daily life, Work and Business, Science and Nature, Culture, Inventions and Discoveries, Arts and Literature, Sports, and Nutrition and Health respectively (Figure 1).

The e-book was given as an e-project to the students as a part of their portfolio task. 24 students of the Foundation course were divided into 4 groups consisting of

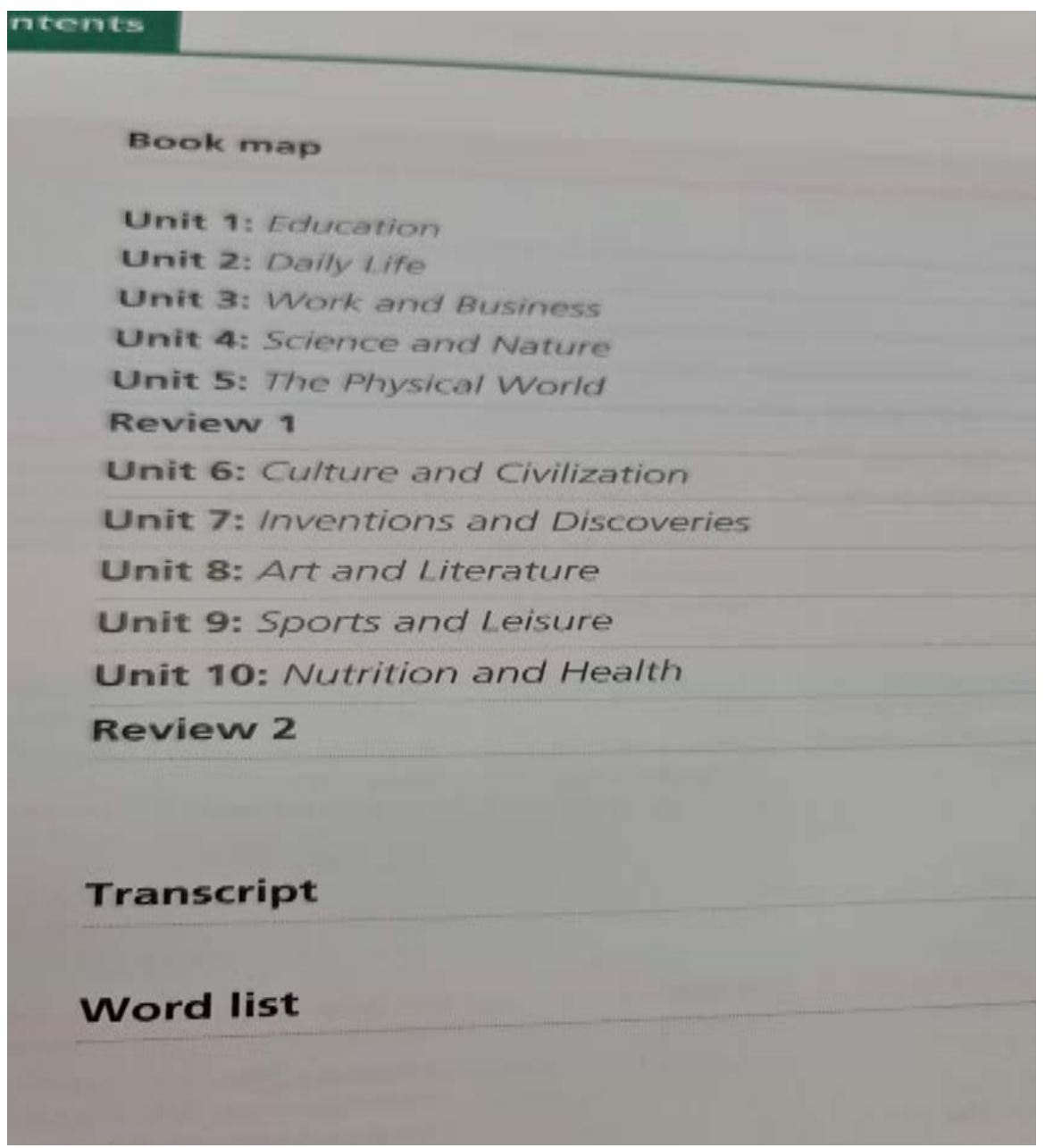

The book map of level 1 Foundation English book (Garnet Progressive Skills).

Figure 1. Content page of English course book. 
6 members. Groups were given the choice to select their country and other countries. Thus one group selected Oman and the other 3 groups selected China, Turkey, and India respectively. Students created the units of their e-book according to the completion of their units in their coursebook. 8-week time was taken to complete the e-project. They use their computer lab each week for creating e-books through "Canva" software. A rubric was formed to assess students' work. The 4 e-books after the submission were projected to the full class for comparing and contrasting their native country with other countries in terms of the concepts learned in their classes.

\section{4) Tools}

The study intended to integrate intercultural study into English classes and analyze the perception of students towards cultural education.

a) Students' e-books were taken to analyze the impact of intercultural education.

b) Collaboration rubric was adopted from "Rubric Resources" created by Dr. Karen Franker (2018) to assess the task done by each group.

c) A small open-ended questionnaire was implemented to get students' perception about intercultural education.

\section{Analysis}

Students' e-books were an eye-opener to a world of customs, tradition, geographical features, literature, and the life process of four different countries. Though the study intended to integrate cultural education into English classes, the main objective was to analyze the impact of cultural education in English classes. Through the e-book project, students could apply the learned concept, vocabulary, form, and structure in a different context. They could contextualize the learned material which enhanced their understanding of the concept and the knowledge of application level. Apart from linguistic skills, they also developed study skills like researching about the topics based on different countries, note-taking, paraphrasing, summarizing, editing, and presenting it colorfully with beautiful background pictures. Students also acquired time management skills as they had to submit each unit of their e-book on the due date which made them utilize time effectively for their project. They did the task collaboratively and cooperatively to share their knowledge and ideas with their group members. Thus the study enhanced their social skills. The students constructed an e-book of their own which enhanced their constructive thinking skills. Moreover, they learned a new technology "Canva", and the way to utilize the software with its options and facilities. Regarding cultural competence, students could relate their culture with others specifically in the field of education, food, clothing, social systems, and literature. They could compare and contrast their culture with others and realize the relevance of their culture in light of others.

A small questionnaire consisting of five questions was implemented to get students' opinions of their e-book project (Figure 2). 


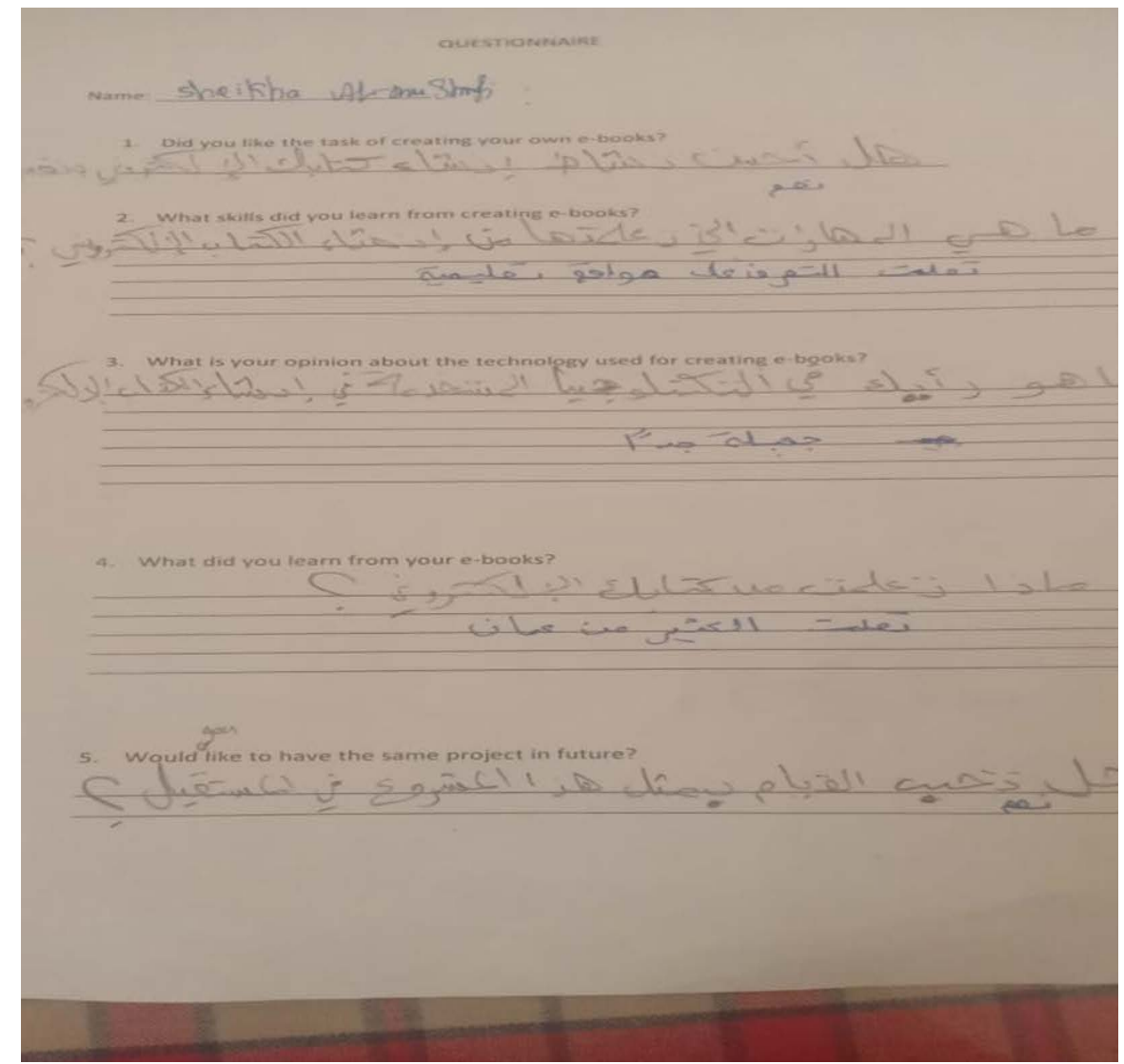

A completed questionnaire in Arabic.

Figure 2. Questionnaire given to the students.

\section{The result is graphically explained below.}

1) The pie chart shows that all students agreed the relevance of the task in their academic program

\section{DO YOU LIKE TO CREATE YOUR OWN BOOKS}

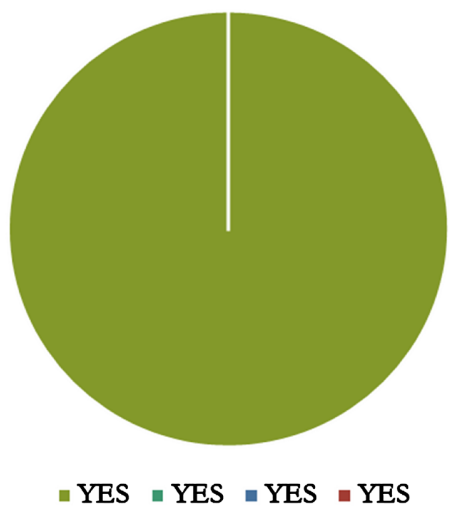

2) The diagram explains the skills acquired by the students. Students acquired different skills, mainly technical followed by linguistic and research skills respectively. Thus the task let them to get acquainted with study skills which are required for their continuous education. 


\section{WHAT SKILLS DID YOU LEARN FROM CREATING E-BOOKS?}

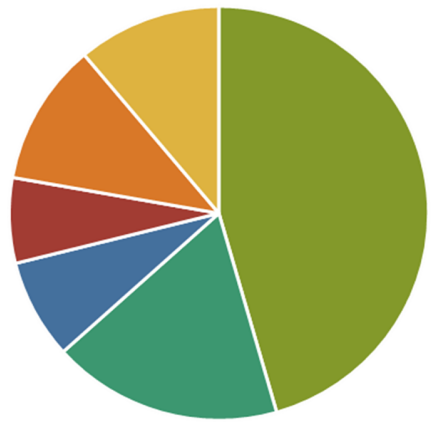

- DESIGN SKILLS - READING SKILIS | WRITING SKIILS

- RESEARCH SKILLS = TECHNICAL SKIILS " NEW SOFTWARE

3) The chart shows students' perception about the technology they used. Students highly preferred the "Canva" graphic website that was used for designing their e-books. The website was easy to use and was helpful in improving their technical skills and highly recommended to have the program in their future learning process.

\section{WHAT IS YOUR OPINION ABOUT THE TECHNOLOGY USED?}

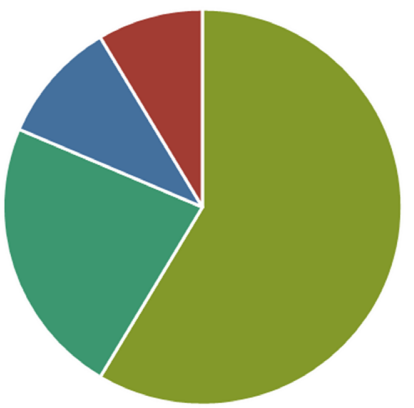

- HELPFUL - USER FRIENDLY ॥ IMPROVE IT SKIIIS - MUST HAVE PROGRAMME

4) The chart explains that the main benefits they got from this approach were self-autonomy, digital learning, and cultural awareness in language learning process. The students got trained to work cooperatively in a very systematic way.

\section{WHAT DID YOU LEARN FROM E-BOOK}

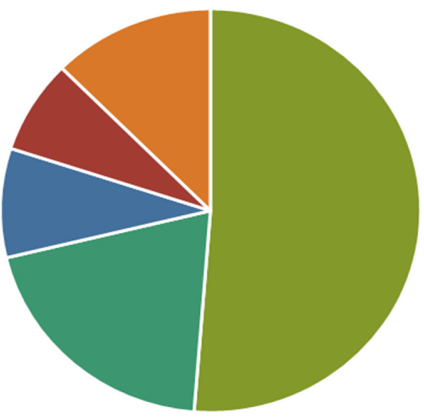

- SELF STUDY $\backsim$ DIGITAL WORKING $\backsim$ DIFFFERENT CULTURES

- GROUP WORK = TIME MANAGEMENT 
5) The chart shows the positive response of the students in having a project and prefers to have the same approach in their future classes.

\section{WOULD YOU LIKE TO HAVE THE SAME PROJECT IN FUTURE}

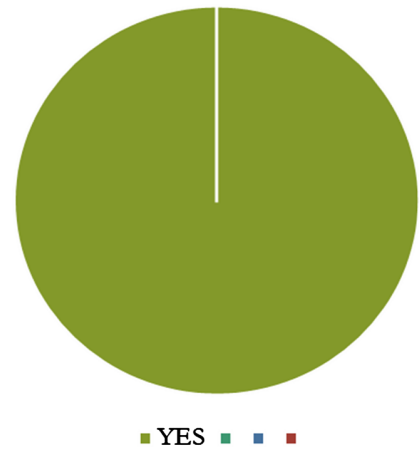

\section{Conclusion}

Technology-based cultural education in English classes was different from the conventional form of methods. Very little research has been conducted with technology based culture learning in English classes, because they were primarily based on grammar and translation methods for decades. The conventional system of teaching and learning process got changed with the advent of technology that paved the way to the world of actual usage of language in a different context. Technology leads to collaborative learning with authentic materials (Moore, 1999). This study also tried to come out from the conventional method and tried technology for optimum utilization of the available resources and methods. The study indirectly used all the authentic materials for collecting the details of each country, the course book, pictures of different cultures, literature of different cultures, and new software to present it technically in a new format. Thus, the study paved a new way of integrating cultural education in English classes. It also created a platform for students to reflect about their culture in the background of different contexts. Tutors need to be proactive in planning and implementing culture-related activities in a way that suits the needs of the students. In a $21^{\text {st }}$ century classroom, the students need to be adept in technical accuracy and proficient in language usage in different situations. Thus culturally relevant pedagogy should be introduced and implemented in English classes as the main objective of English is to communicate with people from different parts of the world.

\section{Conflicts of Interest}

The authors declare no conflicts of interest regarding the publication of this paper.

\section{References}

Abbaspour, E., Nia, M. R., \& Zare, J. (2012). How to Integrate Culture in Second Lan- 
guage Education? Journal of Education and Practice, 3, 20-24.

Agar, M. (1994). Language Shock: Understanding the Culture of Conversation. New York: William Morrow and Company.

Al Hsani, F. (2010). The Pros and Cons of integrating Culture into EFL/ESL. In R. Al Mahrooqi, \& V. Tuzlukova (Eds.), The Omani ELT Symphony: Maintaining Linguistic and Socio-Cultural Equilibrium (p. 203). Sultan Qaboos University-Academic Publisher Board.

Al Seyabi, F. (2010). Promoting Oman's Cultural Heritage through ELT. In R. Al Mahrooqi, \& V. Tuzlukova (Eds.), The Omani ELT Symphony: Maintaining Linguistic and Socio-Cultural Equilibrium (p. 71). Sultan Qaboos University-Academic Publisher Board.

Al-Siyabi, J. (2012). Cultural Universalities and Particularities: A Case Study of Omani EFL SQU Students. In R. Al-Mahrooqi (Ed.), Issue in Teaching and Learning English as a Foreign Language in the Arab World. SQU Academic Publishing Board.

British Council (2013). Languages for the Future: Which Languages the UK Needs Most and Why.

https://www.britishcouncil.org/sites/default/files/languages-for-the-future-report-v3.p df

Brooks, N. (1964). Language and Language Learning (2nd ed.). Harcourt Brace Jovanovich, Inc.

Brown, H. D. (2007). Principles of Language Learning and Teaching (5th Ed.). New York: Longman

Buchs, C., \& Maradan, M. (2021). Fostering Equity in a Multicultural and Multilingual Classroom through Cooperative Learning. Intercultural Education, 32, 401-416. https://doi.org/10.1080/14675986.2021.1889985

Chlopek, Z. (2008). The Intercultural Approach to EFL Teaching and Learning. English Teaching Forum, 4, 10-19.

Dema, O., \& Moeller, A. K. (2012). Teaching Culture in the 21st Century Language Classroom. In T. Sildus (Ed.), Touch the World: Selected Papers from the 2012 Central States Conference on the Teaching of Foreign Languages (pp. 75-91). Faculty Publications: Department of Teaching, Learning and Teacher Education.

http://digitalcommons.unl.edu/teachlearnfacpub/181

Englebert (2004). Character or Culture? An EFL Journal, 24, 37-41.

Franker, K. (2018). Creating and Using Rubrics for Assessment. https://www.uwstout.edu/academics/online-distance-education/online-professional-de velopment/educational-resources-rubrics/creating-and-using-rubrics-assessment

Fushino, K. (2011). Students' Reactions to a Group Project in a University English-as-aForeign-Language Class for Cultural Understanding. Intercultural Education, 22, 301-316. https://doi.org/10.1080/14675986.2011.617423

Ho, S. T. K. (2009). Addressing Culture in EFL Classrooms: The Challenge of Shifting from a Traditional to an Intercultural Stance. Electronic Journal of Foreign Language Teaching, 6, 63-76.

Kaikkonen, P. (2001). Intercultural Learning through Foreign Language Education. In V. Kohonen, R. Jaatinen, P. Kaikkonen, \& J. Lehtovaara (Eds.), Experiential Learning in Foreign Language Education (pp. 61-105). Routledge.

https://doi.org/10.4324/9781315840505-3

Karabinar, S., \& Guler, C. Y. (2012). The Attitudes of EFL Teachers towards Teaching Culture and Their Classroom Practices. Journal of Educational and Social Research, 2, 113-126. 
Ladson-Billings, G. (1995). But That's Just Good Teaching! The Case for Culturally Relevant Pedagogy. Theory into Practice, 34, 159-165.

https://doi.org/10.1080/00405849509543675

Lee, J.S. (2010). Culturally Relevant Pedagogy for Immigrant Children and English Language Learners. Teachers College Record, 115, 453-473. https://doi.org/10.1177/016146811011201408

Mao, W. (2009). Teaching Culture Within and Beyond Language. English Language Teaching, 2, 144-148. https://doi.org/10.5539/elt.v2n4p144

Moore, Z. (1999). Technology and Teaching Culture in the L2 Classroom: An Introduction. Journal of Educational Computing Research, 20, 1-9. https://doi.org/10.2190/97DL-633H-2UDU-NE3X

Naqeeb, H. (2012). Promoting Cultural Literacy in the EFL Classroom. Global Advanced Research Journal of Educational Research and Reviews, 1, 41-46.

Nykiel-Herbert, B. (2010). Iraqi Refugee Students: From a Collection of Aliens to a Community of Learners: The Role of Cultural Factors in the Acquisition of Literacy by Iraqi Refugee Students with Interrupted Formal Education. Multicultural Education, 17, 2-14.

Pereira, F. M. (2016). From Non-Cultural to Intercultural Principles: A Proposal for English Classes in Brazilian Public Schools. Intercultural Education, 27, 577-586. https://doi.org/10.1080/14675986.2016.1249634

Purba, H. (2011). The Importance of Including Culture in EFL Teaching. Journal of English Teaching, 1, 44-56. https://doi.org/10.33541/jet.v1i1.51

Raddawi, R. (2015). Intercultural Communication with Arabs: Studies in Educational, Professional and Societal Contexts. Springer. https://doi.org/10.1007/978-981-287-254-8

Ritlyova, A. (2009). Cultural Studies in Language Teaching. In M, Ferenčík, \& J. Horváth (Eds.), Language, Literature, and Culture in a Changing Transatlantic World International Conference Proceedings (pp. 93-97). Slovenskárepublika.

Sayed, F. (2015, December 18). A Few Surprising Facts about the Arabic Language. British Council.

https://www.britishcouncil.org/voices-magazine/surprising-facts-about-arabic-languag e

Tavares, R., \& Cavalcanti, I. (1996). Developing Cultural Awareness in EFL Classrooms. English Forum, 34, 1-18.

Tuzlukova, V., \& Al Mahrooqi, R. (2010). The Omani ELT. In R. Al Mahrooqi, \& V. Tuzlukova (Eds.), The Omani ELT Symphony: Maintaining Linguistic and Socio-Cultural Equilibrium (p. 33). Sultan Qaboos University-Academic Publication Board.

Wei, L. (2013). Integration of Multicultural Education into English Teaching and Learning: A Case Study in Liaoning Police Academy. Theory and Practice in Language Studies, 3, 612-619. https://doi.org/10.4304/tpls.3.4.612-619

Yurtsever, A., \& Özel, D. (2021). The Role of Cultural Awareness in the EFL Classroom. Turkish Online Journal of Qualitative Inquiry, 12, 102-132.

https://doi.org/10.17569/tojqi.776499

Zhao, B. (2010). How to Enhance Cross-Cultural Awareness in TEFL. Cross-Cultural Communication, 6, 100-104. 


\section{Appendix}

Students' e-books links

https://drive.google.com/file/d/1uDI0TAaDH6oFwIvZEh5isfUXISmHHdAG/view? usp=sharing

https://drive.google.com/file/d/1XL6Uv3ct0yg3ha9 7YtulBUBTjGXZg6r/view?usp=sharing

https://drive.google.com/file/d/0B3rk3oEO7SThWTY3V1hLbm5PUUFmT2RMUmNudDFmRmlDazlR/view?usp=sh aring\&resourcekey $=0$-rBEjxMyZ4CW8wH4FBemhEw

https://drive.google.com/file/d/0B3rk3oEO7SThT3Nwan/RTHdwSVpUOEhMc3hEMXF2cVJrbVdV/view?usp=shari ng\&resourcekey $=0$-eTzM982q6tn8jgl43iy6BA

\begin{tabular}{|c|c|c|c|c|c|}
\hline ATEGORY & Exemplary & Proficient & Partially Proficient & Unsatisfactory & POINTS \\
\hline \multirow{3}{*}{$\begin{array}{l}\text { Focus on the } \\
\text { Task and } \\
\text { Participation }\end{array}$} & 3 points & 2 points & 1 point & 0 points & -13 \\
\hline & $\begin{array}{l}\text { Consistently stays focused } \\
\text { on the task and what needs } \\
\text { to be done. Very } \\
\text { self-directed. }\end{array}$ & $\begin{array}{l}\text { Focuses on the task } \\
\text { and what needs to } \\
\text { be done most of the } \\
\text { time. Other group } \\
\text { members can count } \\
\text { on this person. }\end{array}$ & $\begin{array}{l}\text { Focuses on the task and } \\
\text { what needs to be done } \\
\text { some of the time. Other } \\
\text { group members must } \\
\text { sometimes remind this } \\
\text { person to keep on task. }\end{array}$ & $\begin{array}{l}\text { Rarely focuses on the } \\
\text { task and what needs to be } \\
\text { done. Lets others do the } \\
\text { work. }\end{array}$ & \\
\hline & $\begin{array}{l}\text { A true team member who } \\
\text { contributes a lot of effort, and } \\
\text { encourages and supports the } \\
\text { efforts of others in the group. }\end{array}$ & $\begin{array}{l}\text { A strong group } \\
\text { member who tries } \\
\text { hard! }\end{array}$ & $\begin{array}{l}\text { Sometimes a } \\
\text { satisfactory group } \\
\text { member who does what } \\
\text { is required }\end{array}$ & $\begin{array}{l}\text { Sometimes chooses not } \\
\text { to participate and does } \\
\text { not complete assigned } \\
\text { tasks. }\end{array}$ & \\
\hline \multirow{3}{*}{$\begin{array}{l}\text { Dependability } \\
\text { and Shared } \\
\text { Responsibility }\end{array}$} & 3 points & 2 points & 1 point & 0 points & -13 \\
\hline & $\begin{array}{l}\text { Consistently punctual for } \\
\text { group meetings, turns in all } \\
\text { work on time. }\end{array}$ & $\begin{array}{l}\text { Usually punctual for } \\
\text { group meetings, } \\
\text { turns in most work } \\
\text { on time. }\end{array}$ & $\begin{array}{l}\text { Sometimes late for } \\
\text { group meetings, } \\
\text { frequently turns in } \\
\text { work after the deadline. }\end{array}$ & $\begin{array}{l}\text { Late for all or most group } \\
\text { meetings, misses all } \\
\text { deadlines for turning in } \\
\text { work. }\end{array}$ & \\
\hline & $\begin{array}{l}\text { Follows through on assigned } \\
\text { tasks and does not depend } \\
\text { on others to do the work, } \\
\text { responsibility for tasks is } \\
\text { shared evenly. }\end{array}$ & $\begin{array}{l}\text { Follows through on } \\
\text { most assigned tasks. }\end{array}$ & $\begin{array}{l}\text { Does not follow } \\
\text { through on most } \\
\text { assigned tasks and } \\
\text { sometimes depends on } \\
\text { others to do the work. }\end{array}$ & $\begin{array}{l}\text { Seldom or never follows } \\
\text { through on assigned } \\
\text { tasks. Depends on others } \\
\text { to do all of the work. }\end{array}$ & \\
\hline Listening, & 3 points & 2 points & 1 point & 0 points & 13 \\
\hline $\begin{array}{l}\text { Questioning and } \\
\text { Discussing }\end{array}$ & $\begin{array}{l}\text { Respectfully listens, interacts, } \\
\text { discusses and poses questions } \\
\text { to all members of the team } \\
\text { during discussions and helps } \\
\text { direct the group in reaching } \\
\text { consensus. }\end{array}$ & $\begin{array}{l}\text { Respectfully listens, } \\
\text { interacts, discusses } \\
\text { and poses questions } \\
\text { to others during } \\
\text { discussions. }\end{array}$ & $\begin{array}{l}\text { Has some difficulty } \\
\text { respectfully listening } \\
\text { and discussing, and } \\
\text { tends to dominate } \\
\text { discussions. }\end{array}$ & $\begin{array}{l}\text { Has great difficulty } \\
\text { listening, argues with } \\
\text { teammates, and is } \\
\text { unwilling to consider other } \\
\text { opinions. Impedes group } \\
\text { from reaching consensus. }\end{array}$ & \\
\hline \multirow{2}{*}{$\begin{array}{l}\text { Research and } \\
\text { Information-Sha } \\
\text { ring }\end{array}$} & 3 points & 2 points & 1 point & 0 points & 13 \\
\hline & $\begin{array}{l}\text { Routinely gathers research } \\
\text { and shares useful ideas when } \\
\text { participating in the group } \\
\text { discussion. Defends/rethinks } \\
\text { ideas relating to the group's } \\
\text { project goals. }\end{array}$ & $\begin{array}{l}\text { Usually provides } \\
\text { useful research and } \\
\text { ideas when } \\
\text { participating in the } \\
\text { group discussion. }\end{array}$ & $\begin{array}{l}\text { Sometimes provides } \\
\text { useful research and } \\
\text { ideas when } \\
\text { participating in the } \\
\text { group discussion. }\end{array}$ & $\begin{array}{l}\text { Rarely provides useful } \\
\text { research or ideas when } \\
\text { participating in the group } \\
\text { discussion. }\end{array}$ & \\
\hline
\end{tabular}




\section{Continued}

Problem-Solving 3 points

Actively looks for and suggests solutions to problems.

$\begin{array}{ll}\begin{array}{l}\text { Group/Partner } \\ \text { Teamwork }\end{array} & \begin{array}{l}\text { Consistently makes } \\ \text { necessary compromises to } \\ \text { accomplish a common goal }\end{array} \\ & \begin{array}{l}\text { Always has a positive } \\ \text { attitude about the task(s) } \\ \text { and the work of others. }\end{array} \\ & \begin{array}{l}\text { All team members } \\ \text { contributed equally to the } \\ \text { finished project. }\end{array}\end{array}$

Performed all duties of assigned team role and contributed knowledge, opinions, and skills to share with the team. Always did the assigned work.

$$
\begin{aligned}
& 2 \text { points } \\
& \text { Refines solutions } \\
& \text { suggested by others. } \\
& 2 \text { points } \\
& \text { Usually makes } \\
& \text { necessary } \\
& \text { compromises to } \\
& \text { accomplish a } \\
& \text { common goal. }
\end{aligned}
$$

1 point

0 points 13

Refines solutions Does not suggest or Does not try to solve suggested by others. refine solutions, but is problems or help others willing to try out solve problems. solutions suggested by others

Usually has a positive attitude about the task(s) and the work of others.

Assisted group/partner in the but did not assist finished project.

1 point

Occasionally makes compromises to accomplish a common goal, and sometimes helps keep the group working well together.

Occasionally is publicly Is often negative and critical of the task(s) or publicly critical of the the work of other task(s) or the work of members of the group. other members of the group.

Finished individual task Contributed little to the group/partner during project. the project.

Performed nearly all Performed a few duties Did not perform any duties of assigned of assigned team role duties of assigned team team role and contributed knowledge, opinions, and skills to share with the team. Completed and contributed a small role and did not amount of knowledge, contribute knowledge, opinions, and skills to opinions or skills to share share with the team. with the team. Relied on Completed some of the others to do the work. assigned work.

most of the assigned

work.

COPYRIGHT 2007-2016 Dr. Karen Franker (2018): retrieved from

https://www2.uwstout.edu/content/profdev/rubrics/secondaryteamworkrubric.htm. 